\title{
Tribute to Paul Buck
}

Paul Buck passed away on January 16, 2008. Respected and admired by his colleagues and friends, he left a legacy of lifelong commitment to ecology and botany.

Paul was a founding member of the Board of Directors of the Oklahoma Native Plant Society in 1987, and, after serving on its board for several subsequent terms, he was the second recipient of the ONPS Service Award.

In the early days of ONPS he was an active leader and participant in Society field excursions throughout the state. Paul was at the organizing core of the ONPS Color Oklahoma Committee, serving on its first board from 2003 through 2006.

For more than ten years he wrote a column entitled "Botany Bay" for the ONPS quarterly newsletter, Gaillardia. In each issue he presented a puzzling or intriguing botanical problem and then decoded it in colorful terms, accessible to both amateur and professional botanists.

Most knew Paul as Professor of Botany at the University of Tulsa. He was there from 1964 to 1987, teaching and inspiring students, majors and non-majors alike. For decades he transported students all over the state to Oklahoma Academy of Science (OAS) Field Meetings and Technical Meetings, to Southwest Association of Naturalists meetings, and on spring break excursions to Mexico and New Mexico He encouraged students to attend the University of Oklahoma Biological Station, which he had attended as a student, and Rocky Mountain Biological Station, at which he taught during the summer.

Paul was the faculty advisor of the TU student chapter of Zero Population Growth. With his colleague, Estelle Levetin, he established the longest pollen record in the U.S., also one of the longest in the world. After Paul retired from the University of Tulsa he continued to curate the Harriet G. Barclay Herbarium there and to teach and guide students.

In the mid-1980s Paul was a founding member of the Flora of Oklahoma Committee, a group of Oklahoma botanists dedicated to writing the Flora of Oklaboma. This has been and continues to be a monumental work to write and update keys and descriptions of all the vascular plant species in Oklahoma, replacing the keys of U.T. Waterfall. Paul actively participated in the Flora of Oklahoma Board of Directors until retiring in the spring of 2006 as its Treasurer.

Paul was elected President of the Oklahoma Academy of Science in 1971 and served as Executive Secretary-Treasurer in the late 1980s and early 1990s. He was recognized by OAS for his meritorious service to Oklahoma scientists with the Tenure Service Award in 1991, the Education Service Award in 1994, and the OAS Lifetime Achievement Award presented at a botanical symposium in his honor in 2006. OAS continues to publish Paul's Distribution and Identification of Woody Plants of Oklahoma in the Winter Condition (1983).

Paul was founder of the Mary Kay Oxley Nature Center, a natural area along Bird Creek at the edge of Mohawk Park in Tulsa. Along with Harriet Barclay, he was instrumental in encouraging The Nature Conservancy to purchase both Red Bud Valley Nature Preserve in 1970 and the Tall Grass Prairie Preserve in 1989. He served on the boards of all three of these organizations for many years until they were well established. He also served on the board of The Oklahoma Nature Conservancy.

Many are surprised to learn that Paul Buck was not a native Oklahoman. He was born in Lansing, Michigan, September 9, 1927. At 17 he joined the US Navy and was stationed in Norman, Oklahoma. On leave 
in Tulsa, he met Lou Ann Clark, whom he later married. In Tulsa he served on the Tulsa Police Force as a "beat cop" in Oakhurst in west Tulsa. Working the night shift enabled him to attend classes at the University of Tulsa during the day. There he was inspired by Harriet Barclay and Ralph Kelting to pursue a career in botany. After his BS and MS at UT, he attended the University of Oklahoma where he worked with Elroy Rice. His dissertation, Relationships of Woody Vegetation of the Wichita Mountains Wildlife Refuge to Geological Formations and Soil Types, was among the first ecological studies of the Wichita Refuge. In 2002 Oklahoma Native Plant Record published "Vascular Plants of the Wichita Mountains", from an informational pamphlet previously used by Refuge biologists, which was based on that work.

Paul's commitment to botany, ecology, and environmental conservation extended beyond formal and academic venues. $\mathrm{He}$ involved neighborhood children in observing the natural world. Paul was active in community and student efforts to start recycling programs. He led Boy Scout trips to Philmont in New Mexico and spoke to citizen groups at the Tulsa Library. He rode his bicycle to campus for years, attired in a tuxedo. Paul even rode his bicycle to his daughter's wedding. He lived his commitment to conservation and never lost his joy and wonder at the beauty and complexity of the natural world.

Nothing in this formal description can convey the serene and honorable way in which Paul conducted his life. As he mentored and encouraged students, he persisted in his community activism and cared for his mentor and colleague, Harriet Barclay in her later years. He did so with kindness and good humor. Nor can it convey the remarkable grace with which he accepted the unfairness and disability of Parkinson's disease as it limited his field experiences in his own later years.

Paul was remembered in a memorial service May 3, 2008 at the Harriet G. Barclay Nature Center at Red Bud Valley. It was a glorious spring afternoon, sun shining, gentle breeze - Oklahoma at its best. Family and friends, colleagues and former students, neighbors and community activists were all in attendance, remembering the life of the man who had formed, shared, or changed their lives and left this world a better place for his having been here.

Paul is survived by Lou Ann Clark Buck, his wife of more than fifty years, and by his children, Paul Buck III of Gunnison, Colorado and Dana Buck of Atlanta, Georgia. Intellectually and inspirationally, he is survived by us all. Paul's knowledge of the natural world and his tireless pursuit of its further understanding inspired students, future scientists, and laymen for more than five decades. His gentle manner, his patience, his persistence, and his kindness, even in the face of personal, professional, political, and environmental adversity, make him a model for each of us as we continue his commitment to the botany and ecology of Oklahoma.

Constance Murray, 1 June 2008

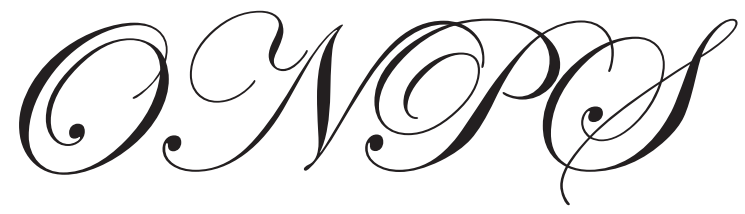

